ARTIGO

\title{
DESAFIOS NO PROCESSO DE ESCOLARIZAÇÃO DE CRIANÇAS COM AUTISMO NO CONTEXTO INCLUSIVO: DIRETRIZES PARA FORMAÇÃO CONTINUADA NA PERSPECTIVA DOS PROFESSORES
}

\author{
SÍGLIA PIMENTEL HÖHER CAMARGO ${ }^{1}$ \\ ORCID: https://orcid.org/0000-0001-7058-6519 \\ GABRIELLE LENZ DA SILVA ${ }^{2}$ \\ ORCID: https://orcid.org/0000-0002-5112-966X \\ RENATA OLIVEIRA CRESPO 3 \\ ORCID: https://orcid.org/0000-0001-6776-3799 \\ CALLEB RANGEL DE OLIVEIRA ${ }^{4}$ \\ ORCID: https://orcid.org/0000-0003-4609-7541 \\ SUELEN LESSA MAGALHÃES ${ }^{5}$ \\ ORCID: https://orcid.org/0000-0002-7190-810X
}

\begin{abstract}
RESUMO: Este estudo investigou as principais dificuldades, os desafios e as barreiras diárias enfrentados por professores de alunos com Transtorno do Espectro do Autismo (TEA) em situação de inclusão na escola comum. Participaram 19 professores cujos alunos com diagnóstico médico prévio de TEA são incluídos em escolas regulares e públicas de Pelotas/RS. Os dados foram coletados através de um roteiro de entrevistas semiestruturado e analisados a partir da análise de conteúdo. Os resultados apontam para a necessidade de fornecer atividades de formação continuada que sejam menos gerais e mais focadas nas necessidades dos professores, sobretudo quanto aos aspectos comportamentais (como lidar) e pedagógicos (como ensinar e avaliar) para, assim, criar condições favoráveis à aprendizagem e ao desenvolvimento dos alunos com TEA no ambiente inclusivo.
\end{abstract}

Palavras-chave: inclusão; autismo; formação continuada de professores.

\section{CHALLENGES IN THE EDUCATIONAL PROCESS OF CHILDREN WITH AUTISM IN INCLUSIVE SETTING: GUIDELINES FOR CONTINUING EDUCATION IN THE TEACHERS' VIEW}

\footnotetext{
${ }^{1}$ Universidade Federal de Pelotas (UFPel). Pelotas, RS, Brasil. <sigliahoher@yahoo.com.br>

${ }^{2}$ Universidade Federal de Pelotas (UFPel). Pelotas, RS, Brasil.<gabelenz@hotmail.com>

${ }^{3}$ Universidade Federal de Pelotas (UFPel). Pelotas, RS, Brasil.<reecrespo@gmail.com>

${ }^{4}$ Universidade Federal de Pelotas (UFPel). Pelotas, RS, Brasil. <calleb.oliveira@gmail.com>

${ }^{5}$ Universidade Federal de Pelotas (UFPel). Pelotas, RS, Brasil. <suelenlessa.85@hotmail.com>
}

ABSTRACT: This study investigated the main difficulties, challenges and barriers faced by teachers of students with Autism Spectrum Disorders (ASD) included in mainstream schools. Nineteen (19) teachers of students with previous medical record of ASD included in general and public schools of 
Pelotas/RS participated of this study. Data were collected through a semi structured interview guide and analyzed through a content analysis technique. The results indicate the need of providing continuing training activities that are less general and more focused in the teachers' needs, especially those related to behavior (how to deal with) e pedagogical (how to teach and evaluate) to create the favorable conditions for learning and development of students with ASD in inclusive setting.

Keywords: inclusion; autism; continuing education for teachers.

\section{DESAFÍOS EN EL PROCESO EDUCATIVO DE NIÑOS CON AUTISMO EN UN ENTORNO INCLUSIVO: DIRECTRICES PARA LA EDUCACIÓN CONTINUA EN LA VISIÓN DE LOS MAESTROS}

RESÚMEN: Este estudio investigó las principales dificultades, desafíos y barreras diarias que enfrentan los maestros que tienen estudiantes con trastorno del espectro autista (TEA) en una situación de inclusión en la escuela ordinaria. Participaron 19 maestros que tienen estudiantes con diagnóstico médico previo de TEA incluidos en escuelas públicas y regulares en Pelotas/RS. Los datos se recopilaron a través de un guión de entrevista semiestructurada y se analizaron en función del análisis de contenido. Los resultados apuntan a la necesidad de proporcionar actividades de educación continua que sean menos generales y más centradas en las necesidades de los docentes, especialmente en lo que respecta a los aspectos conductuales (cómo tratar) y pedagógicos (cómo enseñar y evaluar) para crear condiciones favorables para el aprendizaje. y el desarrollo de estudiantes con TEA en un ambiente inclusivo.

Palabras clave: inclusión; autismo; formación continua de los maestros. 


\section{INTRODUÇÃO}

No Brasil, o atendimento igualitário às demandas educacionais individuais das crianças está legalmente previsto na Constituição Federal de 1988, bem como no Estatuto da Criança e do Adolescente (LEI no 8.069, ECA, 1990) que, em seu artigo 54, parágrafo III, exige a garantia do "atendimento especializado aos portadores de deficiência, preferencialmente na rede regular de ensino". Entretanto, apesar de amplamente discutida no contexto brasileiro, a questão da inclusão vinha mobilizando discretas ações das políticas públicas em relação à concretização dessa proposta de educação (BAPTISTA; VASQUES; RUBLESCKI, 2003). Por essa razão, e sob a égide dos princípios da educação inclusiva, foi elaborada e publicada a "Política Nacional de Educação Especial na Perspectiva da Educação Inclusiva" (BRASIL, 2008). Essa política tem a função de substituir o caráter condicional das leis brasileiras que impediram o avanço da inclusão no país, reforçando os direitos a uma educação inclusiva legalmente prevista e até então não consolidada (ALMEIDA, 2008). Recentemente, a Lei 13.146, de 6 de julho de 2015, institui a Lei Brasileira de Inclusão ou Estatuto da Pessoa com deficiência que, diferentemente dos dispositivos anteriores, tem como objetivo assegurar os direitos fundamentais da pessoa com deficiência, incluindo o direito à educação em escolas regulares, em todos os níveis de ensino.

Diante disso, as questões mais importantes a serem respondidas atualmente, em relação à inclusão escolar de crianças com deficiências, referem-se não somente ao direito dessas crianças frequentarem a escola comum, mas a como educadores podem fornecer uma educação adequada que atenda as necessidades educativas especiais garantindo, assim, progresso e permanência das crianças na escola (MATOS; MENDES, 2015). Nesse sentido, ainda há diversos desafios a serem enfrentados os quais, além disso, continuam a produzir questionamentos e a requerer esforços das políticas públicas e da comunidade acadêmica e científica para que os pré-requisitos de uma efetiva inclusão das diferenças seja garantido.

A literatura nacional aponta que a grande maioria dos educadores não se sente preparada para as demandas exigidas pela inclusão escolar, demonstrando que a atuação do professor é fundamental para que a inclusão escolar ocorra de forma satisfatória (BOSA, 2006; SCHIMIDT et al., 2016). Além disso, para muitos professores, a possibilidade de inclusão de crianças com deficiências se refere àquelas que não necessitam que haja uma reestruturação e adaptação da escola (BOSA; CAMARGO, 2009), como as crianças com Transtorno do Espectro Autista (TEA). Crianças com TEA se caracterizam pela presença de um desenvolvimento atípico na interação social e na comunicação e pela presença de comportamentos e interesses restritos e estereotipados (ASSOCIAÇÃO PSIQUIÁTRICA AMERICANA, 2014). Ademais, comumente não são consideradas em suas habilidades educativas (BAPTISTA; OLIVEIRA, 2002). Devido às características peculiares, que variam de criança para criança, o processo de aprendizagem de alunos com TEA requer adaptações que confrontam os tradicionais métodos de ensino, já que impõem desafios aos professores e superação de barreiras para garantir o direito e a permanência dessas crianças no ensino comum (DUTRA, 2008).

Apesar do sentimento de despreparo dos educadores frente à inclusão, o acesso de alunos com TEA no ensino comum é uma realidade crescente no país. Em virtude do recente decreto da Lei 12.764 (BRASIL, 2012) que, formalmente, caracteriza o autismo como deficiência e proíbe a recusa de matrículas para crianças com esse transtorno no ensino comum, o número de crianças com TEA incluídas nas escolas tende a aumentar. Além disso, o TEA já não é mais classificado como um transtorno raro. No Brasil, embora não existam estudos específicos sobre a incidência do autismo, estima-se que cerca de dois milhões de brasileiros possuem o transtorno (JÚNIOR, 2014). Nos Estados Unidos, onde o avanço de recursos e instrumentos de avaliação padronizados é evidente, falase em uma incidência de autismo de 1 para cada 50 crianças (CENTER FOR DISEASE CONTROL AND PREVENTION, 2013). Portanto, o número de casos vem aumentando no Brasil e no mundo, apontando para a necessidade de um maior investimento nos aspectos educacionais dessas crianças dentro do paradigma da inclusão. Diversos estudos têm apontado o papel do professor para a adequada inclusão de crianças com autismo e o impacto dessa inclusão no desenvolvimento de habilidades acadêmicas, sociais e de comunicação em crianças com TEA (CAMARGO; BOSA, 2012). 
No entanto, a revisão da literatura demonstrou a escassez de estudos que investiguem as principais dificuldades enfrentadas pelos professores frente ao processo educativo da criança com TEA no contexto de inclusão. Dentre os estudos encontrados, na área da psicologia e educação, sobre a inclusão escolar de crianças com autismo, o foco principal divide-se em: a percepção das próprias crianças (BIALER, 2015) pais e professores quanto a essa possibilidade (ANJOS; ANDRADES; PEREIRA, 2009; LEMOS et al., 2016; SANTOS; SANTOS, 2012); os efeitos familiares e escolares da inclusão (GOLDBERG; PINHEIRO; BOSA, 2005; GOMES; MENDES, 2010) e as concepções de professores acerca de seu conhecimento e seu preparo para o trabalho com crianças autistas (FAVORETTO; LAMÔNICA, 2014, SANINI; BOSA, 2015). Algumas pesquisas têm focado no estudo das demandas, dos desafios e das percepções dos professores diante da inclusão (CRUZ et al., 2011; FIORINI; MANZINI, 2016; MATOS; MENDES, 2015; TERRA; GOMES, 2013). No entanto, tratam-se de estudos genéricos em relação às deficiências de modo ou geral ou específico em relação a uma disciplina escolar. Desse modo, tais estudos não investigaram aspectos diretamente relacionados às barreiras diariamente encontradas por professores no processo de inclusão de crianças com autismo para que se possa, a partir da identificação dessas barreiras, criar as condições favoráveis à aprendizagem e ao desenvolvimento dos alunos com TEA. Mais recentemente, Schmidt et al. (2016) realizaram uma síntese da literatura quanto à percepção e às práticas pedagógicas utilizadas por professores de estudantes com autismo a partir da análise de dados secundários oriundos de teses e dissertações. Os autores apontam para a importância da formação continuada para qualificar os serviços educacionais para essa população. Embora os autores mencionem as dificuldades dos professores relatados nos trabalhos incluídos na síntese, estas não eram o foco do estudo que trata-se, atualmente, do único indicador das necessidades específicas dos professores a partir de fontes secundárias. Torna-se, portanto, necessária a realização de estudos que ampliem os achados de Schmidt et al. (2016), a partir do relato direto dos professores, e que forneçam novos e importantes entendimentos sobre as principais dificuldades enfrentadas por eles em relação a estudantes com autismo. Isso permitirá subsidiar futuros programas de capacitação e estudos que visem à investigação e à implementação de estratégias que favoreçam as potencialidades das crianças com autismo em situação de inclusão escolar a partir das necessidades dos alunos e dos professores.

Este estudo, nesse sentido, teve por objetivo investigar, em caráter exploratório, as principais dificuldades, os desafios e as barreiras enfrentadas por professores de alunos com diagnóstico médico prévio de TEA em situação de inclusão na escola comum. Especificamente, buscou-se identificar os principais desafios encontrados pelos professores no processo educativo de estudantes com autismo em situação de inclusão, no que diz respeito ao atendimento das necessidades educacionais especiais desses alunos, e a promoção de habilidades acadêmicas, sociais, comportamentais e de comunicação. Em diferentes níveis, essas habilidades encontram-se prejudicadas em estudantes com autismo e constituem-se em potenciais desafios aos professores e potenciais impedimentos ao sucesso da inclusão desses indivíduos, caso não sejam consideradas e promovidas no processo educativo (BOSA; CAMARGO, 2009). Buscou-se, portanto, mapear as dificuldades específicas dos professores na promoção dessas habilidades permitindo a identificação de aspectos urgentes a serem trabalhados nas capacitações docentes e direcionados em pesquisas futuras para promover uma adequada inclusão de estudantes com autismo.

\section{MÉTODO}

\section{Participantes}

Participaram do estudo 19 professores da rede pública municipal de ensino do Município de Pelotas/RS. Para participação no estudo, deveria cumprir o critério de ser professor de pelo menos um aluno com diagnóstico médico prévio de Transtornos do Espectro Autista (TEA) na sala de aula do ensino comum. Os participantes tinham entre 30 e 60 anos e eram todos do sexo feminino. Das 19 professoras participantes, 14 eram graduadas em Pedagogia e cinco eram formadas somente no magistério. Oito professoras tinham especialização, sendo Psicopedagogia e Educação Especial as mais recorrentes. Três participantes eram professoras da educação infantil e 16 professoras do ensino 
fundamental, todas dos anos iniciais. Somente cinco professoras terminaram a graduação depois de 2008, ou seja, após a elaboração e publicação da Política Nacional de Educação Especial na Perspectiva da Educação Inclusiva.

\section{Procedimentos éticos, de coleta e análise dos dados}

Mediante a anuência da Secretaria Municipal de Educação (SMED), foram sorteadas 20 escolas de cinco diferentes bairros da cidade, incluindo centro e periferias. As escolas sorteadas foram contatadas e foram esclarecidos os propósitos do estudo. Após o assentimento, uma professora de cada escola foi convidada a participar da pesquisa conforme os critérios de participação estabelecidos. Todas as professoras foram contatadas pessoalmente e informadas quanto à natureza e à finalidade do estudo. A entrevista foi realizada individualmente nas dependências da própria escola e gravada na íntegra para posterior transcrição mediante autorização da instituição e da participante que receberam, respectivamente, o termo de assentimento e o termo de consentimento livre e esclarecido com a descrição pormenorizada dos objetivos e procedimentos da pesquisa. Desse modo, foi garantido a todas as participantes o direito de sigilo, a participação voluntária e a interrupção da participação sem prejuízo ao participante, de acordo com a Resolução 466/2012 do Conselho Nacional de Saúde. Um dos 20 participantes solicitou o desligamento do estudo, resultando, portanto, em 19 participantes. O projeto da pesquisa foi submetido à Plataforma Brasil, sendo encaminhado e aprovado por um Comitê de Ética em Pesquisa da Universidade Federal de Pelotas.

Para a coleta dos dados, foi utilizada a técnica de entrevistas individuais, uma vez que essa modalidade permite ao entrevistado expressar livremente suas dúvidas, seus desafios, suas dificuldades e experiências ocorridos na rotina diária com o aluno autista. Como instrumento de coleta de dados, foi elaborado um roteiro de entrevista semiestruturado, com dez questões norteadoras que dão conta de extrair relatos pertinentes aos objetivos da pesquisa. Desse modo, as questões versaram sobre os seguintes eixos: dados pessoais (idade, sexo); titulação e formação dos participantes; qualificação geral da experiência (avaliação da experiência atual) com alunos com autismo; dificuldades e desafios encontrados diariamente no processo de ensino-aprendizagem com o aluno com autismo; e estratégias, práticas, materiais e recursos que utilizam para lidar com tais dificuldades.

Para análise dos dados, foi empregada a metodologia qualitativa de análise de conteúdo proposta por Bardin (1977), que consiste em percorrer os núcleos de sentido nos relatos dos participantes a partir do levantamento e categorização dos temas frequentemente abordados nos enunciados em relação ao assunto investigado. A análise dos relatos das professoras foi percorrida através das etapas de pré-análise, exploração do material, tratamento dos resultados, inferência e interpretação. Assim, as falas das participantes foram agrupadas em categorias e subcategorias de análise a posteriori, observando-se os critérios de recorrência do conteúdo, a intenção da mensagem, a pertinência e a homogeneidade. Desse modo, foi possível identificar e analisar aspectos comuns na experiência das professoras em relação aos alunos com autismo.

\section{RESULTADOS E DISCUSSÃO}

Os dados obtidos foram organizados em três grandes categorias e suas respectivas subcategorias para auxiliar na compreensão e análise. Essas categorias, apresentadas na sequência, foram definidas e organizadas a partir das falas das professoras de acordo com as dificuldades encontradas, as estratégias adotadas para lidar com estas dificuldades e outros aspectos relevantes, tais como a formação e o preparo para ensinar crianças com TEA e os subsídios que julgam necessários para essa tarefa. 


\section{Dificuldades das Professoras}

A Figura 1 sumariza graficamente a primeira categoria denominada "Dificuldades das professoras" as quais incluem aspectos apontados pelas professoras como desafiadores no processo educativo de alunos com TEA.

FIGURA 1: Dificuldades encontradas pelas professoras

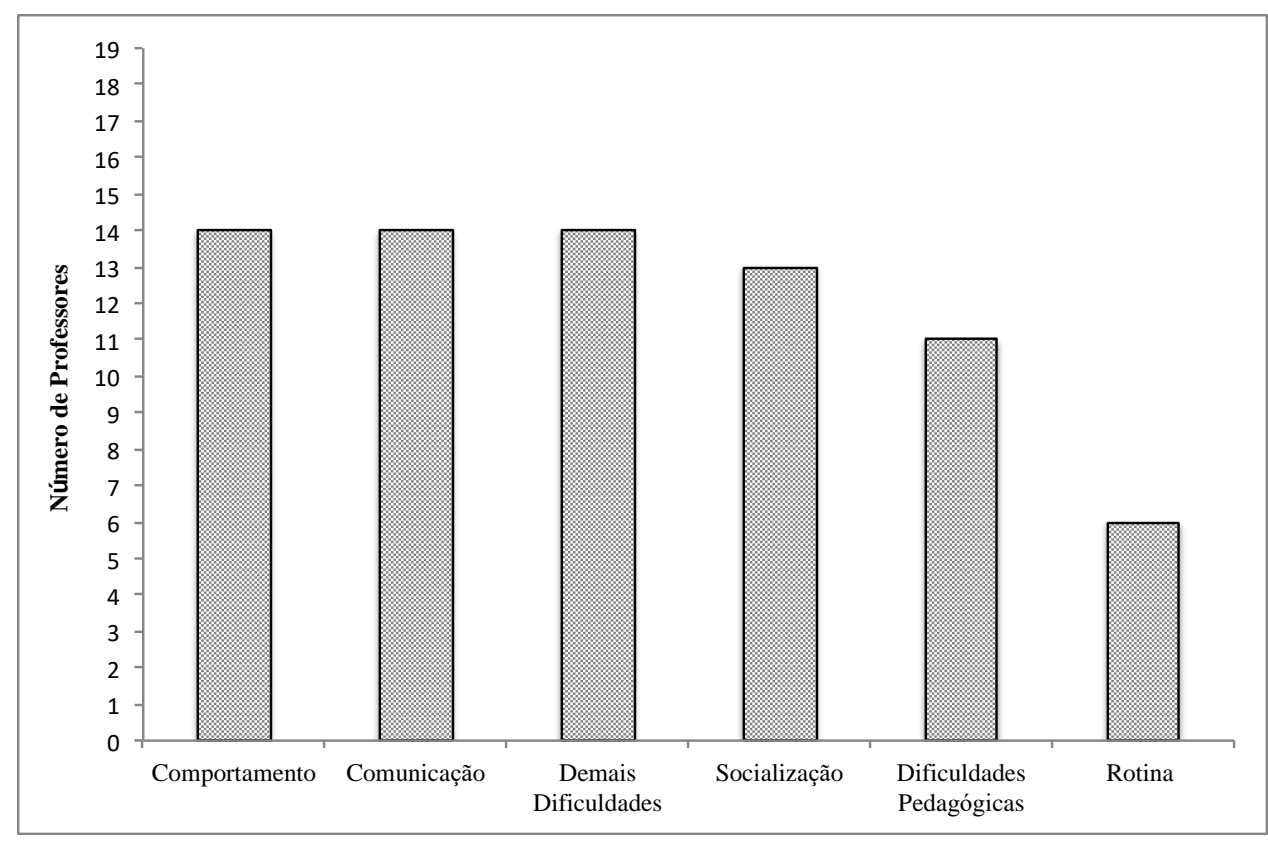

Fonte: Elaborado pelos autores.

Nessa categoria, estão explicitadas as dificuldades encontradas pelas professoras no processo de inclusão de alunos com autismo e que se subdividem em seis subcategorias, quais sejam: comportamento; comunicação; demais dificuldades; socialização; dificuldades pedagógicas e rotina. Há maior recorrência, nas falas das professoras entrevistadas, sobre as dificuldades comportamentais, de comunicação e demais dificuldades - as primeiras se referem aos aspectos comprometidos em indivíduos com TEA, já as demais dificuldades se referem às questões que não estão diretamente ligadas ao aluno, mas à escola e à comunidade em que o aluno está inserido.

O comportamento, uma das áreas que possui desenvolvimento atípico em indivíduos com autismo, foi citado por 14 professoras como uma grande dificuldade no trabalho e na inclusão de crianças com TEA. Dentro do aspecto comportamental, a maior dificuldade apontada foi o manejo de comportamentos atrelados à recusa em fazer atividades/seguir rotinas e regras. Dez professoras relataram ter dificuldade com o aluno em fazer determinadas atividades e/ou seguir a rotina e regras na escola e sala de aula, o que gera comportamentos desafiadores, como demonstra a fala a seguir:

"Essa questão da birra, pode ser feita na hora de que ele não quer mais realizar atividade, talvez pelo limite dele, cansaço, não dá pra gente dizer que é uma birra, mas as vezes ele não quer fazer nada, não sei te dizer, poderia ser uma birra ou cansaço também dele, né." Professora 3.

As dificuldades da criança com TEA em engajar-se em uma atividade escolar pode estar fortemente atrelada a características do transtorno que são relacionadas, por exemplo, a interesses restritos e à inflexibilidade para engajar-se em tarefas não preferidas. Trata-se de um conjunto de características bastante peculiares que se refletem em dificuldades comportamentais que necessitam ser compreendidas a partir do conhecimento dos interesses e das preferências do aluno e suas dificuldades, 
mas que são, como exemplificado acima, frequentemente interpretadas como birra ou recusa proposital.

Interesses restritos e estereotipados das crianças também foram dificuldades apontadas pelas professoras na questão comportamental. Sete professoras relataram ter dificuldades nessa questão. Essas estereotipias diversas, que comumente podem envolver balanço do corpo, agitação das mãos, dentre outros, podem ocorrer em situações tanto de frustração quanto de satisfação da crianças com autismo. Já no ambiente escolar, também estão frequentemente associadas à realização de atividades preferidas e/ou desencadeadas pelas características do TEA, de inflexibilidade frente a interesses restritos que possui e/ou rigidez de sequências de atividades ou disposição de objetos na sala de aula. As professoras demonstraram que esse comportamento é compreendido não pela ótica do que caracteriza o TEA, mas por suposições dos seus objetivos ou como qualidade pessoal de um aluno, conforme as falas abaixo:

\footnotetext{
“Às vezes ele grita, ele sacode as mãos, mexe os dedos, aí eles aprenderam que é uma maneira dele demonstrar que tava feliz. Quando toca alguma música, às vezes ele mexe as mãos, sacode a cabeça, se balança e grita, é como se ele tivesse cantando, eles [os colegas] acham que ele tá cantando, que tá feliz." - Professora 15.

“É, se o lixo muda de lugar ele nota, e vai lá, pega e põe no lugar. Tem coisa assim, que me encanta até nele e tem outros que não se dão conta." - Professora 4.
}

Outro aspecto relatado por sete professoras foi a agressividade, que pode ser direcionada ao professor, aos colegas e a si mesmo e, segundo elas, não tem uma situação desencadeadora aparente. Embora comportamentos agressivos não sejam uma característica ou critério diagnóstico para o autismo, muitos alunos podem apresenta-los. Geralmente, a criança com autismo pode apresentar comportamentos agressivos quando há dificuldade para comunicar alguma insatisfação ou necessidade. Por esse motivo, a ocorrência desses comportamentos exige uma análise contextual cuidadosa, pois todo comportamento tem uma função e suas causas estão frequentemente associadas a fatores relativos ao próprio ambiente em que ocorre. A agressividade foi citada como um obstáculo para o processo de ensino-aprendizagem e também para o relacionamento dos colegas com o aluno com TEA, devido ao medo que ele causa por suas atitudes. É evidente a dificuldade que as professoras têm em explicar e realizar uma análise do contexto e das situações que desencadeiam os comportamentos agressivos:

"Agressividade. Ele torna-se agressivo, inquieto, ele chora, ele joga as coisas pra cima, atira tudo longe, ele agride mesmo. Entendeste!?” - Professora 1.

"Tanto que esses novos que chegaram agora tem esse medo, de que ele vá bater. Então eu tive que explicar que não, que eles não se preocupassem, que a mesma coisa quando ele tem algumas crises, de vez em quando assim, que eu penso que é do nada, mas que deve ter alguma coisa né, ele chega assim, começa a me soquear, e me bater na perna, e aí eu vou falando com calma com ele. Passa e depois parece que não aconteceu nada." - Professora 4.

A comunicação dos alunos com TEA também foi um aspecto bastante desafiador no processo de ensino-aprendizagem, de acordo com as professoras, dentre as quais 14 relataram dificuldades nesse aspecto. A principal dificuldade citada está relacionada com a comunicação do e com o aluno com autismo, sejam dificuldades de compreensão da fala do aluno ou dificuldades por parte dos colegas e dos professores de serem compreendidos por ele e/ou para desenvolver um diálogo interativo e recíproco, como exemplificam os relatos a seguir:

“O J, ele não verbaliza, ele não fala, entendeste? Então... Nesse aspecto aí não tem como né?” - Professora 1.

"Ele não conversa como eu tô conversando contigo, como tu conversaria assim, não desenvolve uma conversa, ele fala, ele pede, ele pode falar, ele pode pedir alguma coisa, mas ele não consegue é falar fluentemente com os colegas, entendeu?” - Professora 3. 
Embora a ecolalia e a estereotipia da fala sejam comuns em indivíduos com TEA, somente três professoras relataram ter dificuldades nesse aspecto provavelmente pelas características dos seus alunos:

"O que ele faz assim, é repetir muito o que a gente fala, né, isso ele faz, é repetir o que tu fala." - Professora 3.

As demais dificuldades, relatadas por 14 professoras, não se referem a desafios relacionados ao aluno com TEA e suas características, mas sim a questões relevantes e presentes no processo de inclusão escolar, como os recursos que possuem, a presença de outros alunos com deficiência na sala de aula, a aceitação do colega com autismo pelos pares típicos e a dificuldade de comunicação com a família. Nessa categoria, nove professoras relataram ter dificuldades para utilizar ou relataram que não utilizavam atividades, materiais e estratégias adaptadas para alunos com TEA, seja pelo fato de o aluno conseguir acompanhar e utilizar os mesmos materiais, atividades e estratégias que eram preparados para o resto da turma ou porque a professora e a escola não dispunham de mais tempo para trabalhar com o aluno um planejamento específico de acordo com suas limitações e potencialidades, como podemos observar:

"Quando eu soube que ia ganhar um aluno autista, eu tinha bastante atividade diferente pra trabalhar com ele, porque eu achei que ele não ia conseguir alcançar os outros, mas ele alcança muito mais, tem muitas outras crianças que não têm autismo, que não têm o potencial que ele tem. Ele é bem além mesmo.” - Professora 13.

"Eu sempre tentei fazer na minha aula as atividades que ele se interessa também, que ele tentasse fazer, que ele tentasse ajudar e com isso nessa questão eu tive dificuldade porque eu não sabia como trabalhar com ele." - Professora 7.

"Eu notava que tinha que ter uma coisa a mais, tinha que ter uma explicação a mais pra ele. Ele precisava de um tempo maior, um tempo que a gente não tem quando tem toda a sala de aula." - Professora 5.

A fala anterior remete a outra dificuldade mencionada pelas professoras no processo de inclusão de alunos com TEA. Sete professoras relataram ter dificuldade com a diversidade em sala de aula - que inclui não apenas alunos com TEA, mas também outras deficiências - sem, muitas vezes, poder contar com o apoio necessário previsto legalmente, como o serviço de atendimento educacional especializado (AEE) dentro da própria escola ou ainda um professor auxiliar ou cuidador, quando há necessidade. Esses aspectos, que são essenciais para um trabalho de inclusão efetivo (ROPOLI et al., 2010), e essa dificuldade recorrente, confirmada pelas falas das professoras entrevistadas, parecem estar frequentemente associadas a fontes de estresse e de discursos de resistência à proposta da inclusão, como relatou uma professora:

"E essa questão da lei que veio de cima pra baixo, eu queria ver a pessoa que criou a lei da inclusão que queria desmanchar as escolas especiais, vir pra dentro da sala de aula e passar uma tarde inteira com 24 alunos que eles dizem como normais e os outros dois ou três, problemáticos dentro da sala de aula. Porque os problemas, com os normais a gente já tem problemas na sala de aula, imagina com uma criança que nem esse menino." - Professora 10.

Ao mesmo tempo, apesar da dificuldade de algumas professoras em manejar e lidar com a diversidade em sala de aula, poucas professoras relataram ter dificuldades em relação à aceitação do aluno pela turma. Somente três professoras disseram ter dificuldades de incluir o aluno com autismo na sala de aula devido a não aceitação dos colegas. Ainda assim, percebe-se que esse é um ponto crucial para a efetivação da inclusão e que os professores precisam ser orientados a esse respeito (DIAS et al., 2016). Uma das professoras que mencionou essa dificuldade diz trabalhar com os pares a respeito da importância da escolarização do colega com autismo, mas que não foi suficiente e não surtiu efeitos:

"Aí entra o momento da inclusão, que tem o aluno que aceita, e o que não. Com os outros eu conversei, olha: 'Ele é tão meu aluno quanto vocês, ele tá aqui também, é importantíssimo Educação em Revista|Belo Horizonte|v.36|e214220|2020 
pra ele esse momento de interação com vocês’. Eu converso com eles, eles não aceitam.” Professora 1.

Em relação às dificuldades em se comunicar com a família, quatro professoras mencionaram dificuldades em abordar com os pais a necessidade de encaminhamentos diversos para eles ou para as crianças, além de dificuldades com a resistência das famílias ao que é proposto e, sobretudo, em relação ao comprometimento da família com a escolarização do aluno e os serviços especializados que recebem e a continuidade do trabalho feito pela escola em casa.

"Eu tenho mais problemas com a mãe dele, porque ela sim é uma pessoa que não deixa ele ter autonomia, eu deixo." - Professora 13.

"Eu já encaminhei pra acompanhamento psicológico, mas não aceita, tem muita dificuldade, o pai já quis, a mãe não quis, então disse pra ela, então vamo espera, quando tiveres pronta, pra tu aceitares isso." - Professora 1.

Poucas professoras relataram esse tipo de dificuldade com a família. A importância e a contribuição da família para o sucesso escolar das crianças é amplamente relatada na literatura (DESSEN; POLONIA, 2007), sobretudo no que diz respeito a inclusão, uma vez que a importância da parceria família-escola confere a esse aspecto um eixo essencial a ser trabalhado na formação de professores como parte constituinte das práticas educacionais inclusivas (CASTRO; REGATTIERI, 2009).

Dentre os desafios das professoras também estão aqueles em lidar com as dificuldades de socialização do aluno. As professoras fizeram referência às dificuldades de se relacionar com os alunos com TEA e da dificuldade deles em se relacionar com os colegas. Treze professoras relataram dificuldades relativas à socialização do aluno. Essas dificuldades foram recorrentes em diversas falas das professoras e, em alguns casos, poderiam ser um dos principais empecilhos e uma frustração da professora na sala de aula, conforme relato a seguir:

"Acho que a socialização deles é a minha maior dificuldade. Porque eles ficam só no mundo deles assim isolados. Tu não consegue fazer com que eles interajam com os outros colegas. Acho que isso é o mais difícil.” - Professora 16.

O relacionamento do aluno com TEA e seus colegas também apareceu como uma preocupação para as professoras, decorrente das dificuldades de socialização, especialmente pelo afastamento do aluno nas atividades em grupo, como mostram algumas professoras:

"Ele fica só, ele se isola." - Professora 2.

"Eles têm na socialização que é ele o centro, não deixa ninguém chegar perto dele, é difícil dele se entrosar e os outros também. Porque sempre acontece aquilo de 'ah o "R" não vai brincar, porque ele não sabe brincar', aquela coisa toda que mesmo que tu trabalhe, sempre acontece isso." - Professora 13.

A dificuldade de interação social é uma das principais características de crianças com TEA e os aspectos de socialização tornam-se um dos grandes desafios em aula. Nota-se, por parte das professoras, a dificuldade em identificar as razões pelas quais os alunos se isolam e os interesses do aluno com TEA que, quando levados ou não em consideração, podem contribuir para a maior ou menor socialização do aluno com TEA com os colegas:

"Parece que ele não se interessa, não chamou atenção. Não que tenha medo ou que eles tenham medo, não é isso. Mas não tem interação com os colegas” - Professora 12.

Também foi identificada a dificuldade de atrelar o incremento nas habilidades sociais dos alunos com autismo a intervenções planejadas para o estímulo e aprendizagem das habilidades sociais 
que estão prejudicadas, uma vez que isso não ocorre pelo simples fato de estarem em contato com os pares com desenvolvimento típico na escola (GUTIERREZ et al., 2007).

Outro aspecto essencial para a efetiva inclusão de um aluno com TEA é o planejamento e a sistematização do ensino e da avaliação da aprendizagem a partir das suas necessidades e dos seus níveis de conhecimento (SERRA, 2010). No entanto, foi recorrente na fala das professoras o que denominamos de dificuldades pedagógicas, ou seja, as dificuldades na realização do trabalho acadêmico com o aluno com TEA tanto para ensiná-lo, como para avaliar sua aprendizagem. Esse foi um desafio apontado por 11 participantes. Nota-se, no relato das professoras, que existe uma necessidade em separar a aprendizagem efetiva do aluno daquilo que ele memorizou. Essa dificuldade é acompanhada de sentimentos de dúvida e de frustração segundo as professoras:

“É que sinceramente eu não sei o que ele aprendeu né, mas aprendeu algumas coisas né." Professora 7.

"Como é que eu vou saber se ele sabe que o D com o A vai fazer DA? Eu não sei, eu não tenho esse retorno, e eu não sei como fazer isso, entendesse? Então o problema é meu, como eu posso fazer pra melhorar aquilo." - Professora 8.

"É isso da aprendizagem, seria isso como fazer que ele aprenda, é a minha principal dúvida assim, é onde eu me perco mais, como interagir com ele, entendeu? Como fazer ele aprender?” - Professora 18.

Essa dificuldade parece estar relacionada à pouca apropriação das professoras sobre as especificidades do TEA e consequentemente sobre elas não saberem o que e como trabalhar com esses alunos em sala de aula, dificultando seu trabalho de ensino e avaliação:

"Ai, eu fiquei apavorada. Eu fiquei, meu Deus, o que vai acontecer, fiquei apavorada, pensando estratégias pra trabalhar com a turma, pensando o que é que eu vou fazer." Professora 4.

"Eu sempre tentei fazer na minha aula as atividades que ele se interessa também, que ele tentasse fazer que ele tentasse ajudar e com isso nessa questão eu tive dificuldade porque eu não sabia o que trabalhar com ele." - Professora 7.

"O trabalho com ele, a lida com ele é tranquila, o que não é tranquila é a gente pensar atividades pra ele, a gente alcançar ele. E isso é muito angustiante porque a gente tenta, tenta, tenta várias coisas e nem sempre a gente consegue alcançar ele.” - Professora 15.

Esses relatos demonstram que é fundamental que o professor seja orientado, em cursos de formação de professores, sobre recursos e estratégias de ensino para alunos com TEA para que eles estejam, de fato, incluídos e a aprendizagem possa efetivamente ocorrer (LEMOS et al., 2016).

Outra característica marcante que pessoas com TEA em geral possuem é a inflexibilidade com mudanças de rotina e a necessidade de uma rotina organizada e sistemática (HUNDERT, 2009). No entanto, somente três professoras apontaram como um desafio as dificuldades que os alunos têm em seguir a rotina da escola, como sequência de atividades, transições de uma atividade para outra e organização dos materiais:

"É com a nossa orientação e ajuda. Ele não consegue associar que já mudou a atividade, aí tu vai lá, guarda o material dele, ele também não tem ainda essa... Talvez é uma coisa a ser trabalhada no próximo ano pra ele, organizar o material dele. Ele não tem ainda uma independência." - Professora 3.

A organização da rotina é um aspecto essencial para a permanência da criança na escola e deve ser trabalhada e ensinada assim que a criança chega na escola, visando ajudá-la na organização do ambiente e das atividades na busca de autonomia e independência (HUNDERT, 2009). Outro desafio para essas professoras relacionado à rotina é a dificuldade que os alunos com TEA têm com as mudanças repentinas e inesperadas nas atividades diárias de sala de aula. Nos relatos a seguir podemos 
ver que as reações desses alunos com a mudança de rotina são sempre de resistência às mudanças inesperadas. Há necessidade de instruir professores sobre como agir nessas situações cuja rotina necessite ser alterada.

\footnotetext{
"Aquele aniversário nunca fez parte da rotina de sala de aula, tá me entendendo? Então aquilo ali desvirtuou ele do momento, ele chorou o tempo inteiro.” - Professora 3.

"Ele tem dificuldades em sair da rotina, qualquer coisa que seja diferente ele não quer. Por exemplo, um dia a professora me ligou dizendo que ia se atrasar... Aí não quer ficar na sala... Não é a sala dele, né." - Professora 4.
}

Considerando as atividades diárias das professoras, que precisam atender as demandas de uma turma inteira, a falta de recursos e de estratégias práticas e adaptadas, pautadas no conhecimento das características do TEA, é uma dificuldade que impede o progresso do trabalho não só com o aluno com necessidades educacionais especiais, mas com todos os demais alunos. Esse aspecto remete diretamente à sua prática pedagógica diária e às estratégias que utilizam ou deixam de utilizar com esses alunos, conforme a categoria seguinte.

\section{Estratégias utilizadas pelas professoras}

A Figura 2 mostra as estratégias e materiais específicos utilizados pelas professoras no processo de inclusão de alunos com TEA.

FIGURA 2: Estratégias utilizadas pelas professoras

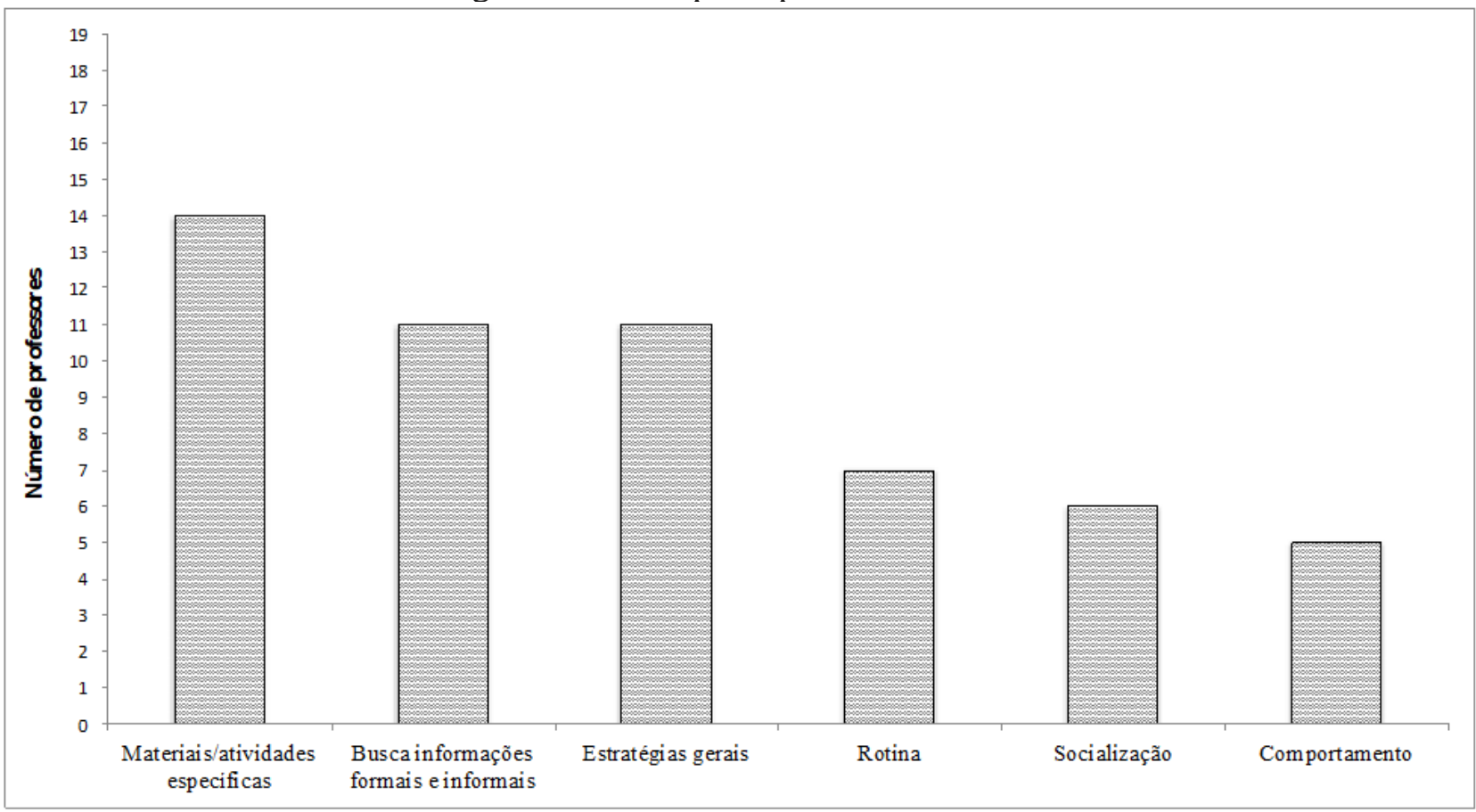

Fonte: Elaborado pelos autores.

Perante as dificuldades das professoras em trabalhar com os alunos com autismo, é importante verificar as estratégias utilizadas por elas para minimizar as situações desafiadoras e tornar a sua prática pedagógica mais eficaz. Embora não necessariamente se baseiem no conhecimento do TEA e do que tem se mostrado mais eficaz para a inclusão dessas crianças, as professoras procuram pensar em algumas estratégias ou alguns recursos que auxiliem o processo educativo desses alunos, seja em relação às questões comportamentais, de socialização ou de rotina, seja relacionado aos métodos de ensino. As professoras relataram procurar por informações que viabilizassem o trabalho e diminuíssem a sua aflição, assim como que proporcionassem a permanência e o desenvolvimento de seus alunos 
com autismo. Onze professoras buscaram informações formais, ou seja, auxílio profissional com a professora do AEE, com a psicopedagoga, a direção e coordenação da escola, em livros ou cursos adicionais. Além disso, elas também mencionaram a busca por auxílio em fontes informais, através da família dos alunos com TEA e em meios não necessariamente confiáveis, como a internet, conforme descrito na fala abaixo:

"Tenho que sempre estar recorrendo à coordenação ou à sala de recurso ou à internet, para ver como posso trabalhar com ele, como lidar.” - Professora 18.

A busca por materiais ou atividades específicas está presente nos relatos das 14 professoras que tentaram, de várias maneiras, tornar efetiva a inclusão dos seus alunos com autismo. Os materiais e as atividades utilizados e mencionados por elas vão desde massinha de modelar, pinturas, joguinhos de encaixe, quebra-cabeça, letras e números em EVA, livros, folhas, atividades de pareamento, recorte até outras tantas que elas julgaram ser pertinentes para trabalhar na sala de aula com crianças com autismo. Percebe-se que existe uma preocupação e intenção das professoras em ensinar os alunos com TEA utilizando vários recursos, mas nota-se que esses recursos são utilizados distintamente com esses alunos, sem existir uma relação com o conteúdo trabalhado em sala de aula com os demais alunos, o que se torna, portanto, uma prática contraditória aos princípios da inclusão. A fala da professora destaca esse aspecto:

\footnotetext{
"Todo o material pra ele é diferenciado. Até no início do ano a gente conseguia fazer com que, se os outros tavam rasgando papel ele rasgava também. Hoje que os demais já escrevem, já leem, as atividades já são diferenciadas, todo o material dele é diferente assim. As atividades dele ficam numa caixa e ali ele sabe a atividade que vai vir. O material dele é todo diferente dos demais." - Professora 15.
}

A ausência de informações e de conhecimentos na formação inicial, bem como durante a prática profissional, são grandes desafios para as professoras. Para uma prática pedagógica realmente inclusiva, é necessário e fundamental o entendimento de que o que deve ser diferenciado ou adaptado não é o currículo, o conteúdo ou a atividade para o aluno com deficiência, e sim a forma e os recursos é que devem se adequar às necessidades de aprendizagem da criança para que o mesmo conteúdo e a atividade que os demais alunos sem deficiência praticam sejam ensinados (MANTOAN, 2015).

Onze professoras relataram diversas táticas que utilizam para contornarem as dificuldades encontradas no dia a dia com o aluno com TEA e as quais chamamos de estratégias gerais. Dentre elas, as professoras relataram que mudam objetos e móveis de lugar na sala de aula, usam sistema de trocas com a criança (não necessariamente os formalmente conhecidos como PECS), não forçam a criança a fazer atividades e a deixam fazer o que ela prefere fazer, usam música para acalmar as crises, utilizam Reiki e DVDs preferidos. Com isso, observa-se que as estratégias gerais comumente utilizadas são baseadas no senso comum ou naquilo que elas acreditam ser adequado, apontando para a necessidade de um melhor entendimento sobre o que significa incluir e proporcionar uma educação diferenciada para crianças com autismo ou outras deficiências.

Outra estratégia utilizada pelas professoras é em relação à rotina. Sete entrevistadas relataram haver um horário diferente na entrada ou na saída dos alunos com TEA, pois essa mudança no horário proporcionaria, para eles, uma melhor adaptação na rotina escolar. Algumas professoras destacaram que esse horário deve ser aumentado gradualmente conforme a adaptação dos alunos:

"A gente tem aumentado, primeiro começou vindo até as $15 \mathrm{~h}$, depois passou pras 15:15, a gente foi aumentando de 15 em 15 minutos, ele chegou até as 16:30.” - Professora 4.

Para muitos alunos com autismo e seus professores, adaptar-se e entender a rotina da escola é um desafio. A inserção progressiva do aluno no ambiente escolar pode ser necessária em alguns casos. No entanto, essa não deve ser a única medida a ser tomada em relação à rotina. Sabe-se que compreender e estar ciente da rotina, da sequência de atividades e das mudanças que ocorrem antecipadamente durante o período na escola é fundamental para esses alunos, já que, dessa forma, evitam-se comportamentos reativos que podem desencadear uma série de dificuldades para a 
professora, para os colegas e para a permanência da criança na escola. Contudo, nenhuma das sete professoras mencionou utilizar outros recursos, como uma rotina visual, por exemplo, através de figuras e imagens, que são frequentemente apropriados ao estilo de aprendizagem de alguns indivíduos com autismo para auxiliá-lo a acompanhar a rotina da turma na escola.

Seis professoras relataram utilizar estratégias para incentivar a socialização dos alunos com autismo e incentivar os pares a interagirem com eles proporcionando, assim, diferentes situações, como atividades pedagógicas no pátio, através de brincadeiras, passeios fora da escola. As professoras acreditam que a interação entre os pares pode ajudar no desenvolvimento dos alunos com autismo, mas, novamente, identifica-se, pelas estratégias utilizadas, a dificuldade de perceber as formas adequadas de estimular essa interação, uma vez que suas propostas não são planejadas considerando as especificidades e necessidades dos alunos com o transtorno.

Em relação ao comportamento, cinco professoras relataram que utilizam estratégias para sanar as dificuldades comportamentais apresentadas pelos alunos, como: sistematizar trocas para acalmar; fechar a porta para o aluno não fugir; usar um tom de voz baixo; conversar; usar colchonete para quando a criança se joga no chão, em situação de irritabilidade; e retirar da sala de aula em situações de crise. Percebe-se que as estratégias das professoras para as dificuldades comportamentais dos alunos são principalmente reativas, ou seja, tratam-se de consequências e tentativas de conter o comportamento já instalado, sem a implementação de estratégias de prevenção de crises e de comportamentos inadequados do aluno baseadas no conhecimento dos seus padrões comportamentais. Além disso, as poucas alternativas de recursos de prevenção de comportamentos-problema parecem estar atreladas ao mencionado nas estratégias gerais, que incluem práticas nem sempre validadas e eficazes, sem considerar a análise contextual dos antecedentes e as consequências que podem estar desencadeando ou mantendo o comportamento, como ilustra a fala a seguir:

"Aí eu pedi pra professora de educação física buscar um colchonetezinho, porque ele é tão vivo, né, o D. é tão vivo. O que acontece: ele pegou a manha do colchonetezinho, então ele já sabia que quando ele se atirava a gente botava o colchonete do lado e ele só rolava pra cima do colchonete e ficava ali, tanto que agora quando ele fica brabo a gente diz assim 'pega ali', aí ele vai lá e atira no chão e se atira." - Professora 8.

\section{Outras informações relevantes}

A Figura 3 apresenta os demais aspectos relevantes, mencionados no decorrer das entrevistas, os quais influenciam o trabalho das professoras. Foram mencionadas a falta de preparo, a sensação de despreparo e a necessidade de formação continuada, bem como a qualificação de sua própria experiência com a inclusão de alunos com TEA, as potencialidades e a evolução dos alunos no decorrer desse processo.

A falta de preparo na formação inicial foi um ponto levantado por 16 professoras. A ausência de disciplinas, cursos, materiais e informações específicas influenciam no sentimento de despreparo frente à prática pedagógica com alunos com autismo. Independentemente de ter tido esse preparo, 12 professoras relataram não sentirem-se preparadas para esse trabalho. A inclusão de alunos com TEA na rede regular de ensino causa um desconforto nos professores que se veem sem saber como lidar com as dificuldades e as formas de ser. Esse desconforto torna-se, muitas vezes, o incentivo para a busca de alternativas, aspecto que, segundo estudiosos da inclusão, é fundamental para que a inclusão aconteça (MANTOAN, 2015). Esse ponto é salientado na fala a seguir:

"Não. Eu não me sinto preparada, mas eu sou corajosa, entende? A gente vai enfrentando a situação." - Professora 2. 
FIGURA 3: Outras informações relevantes

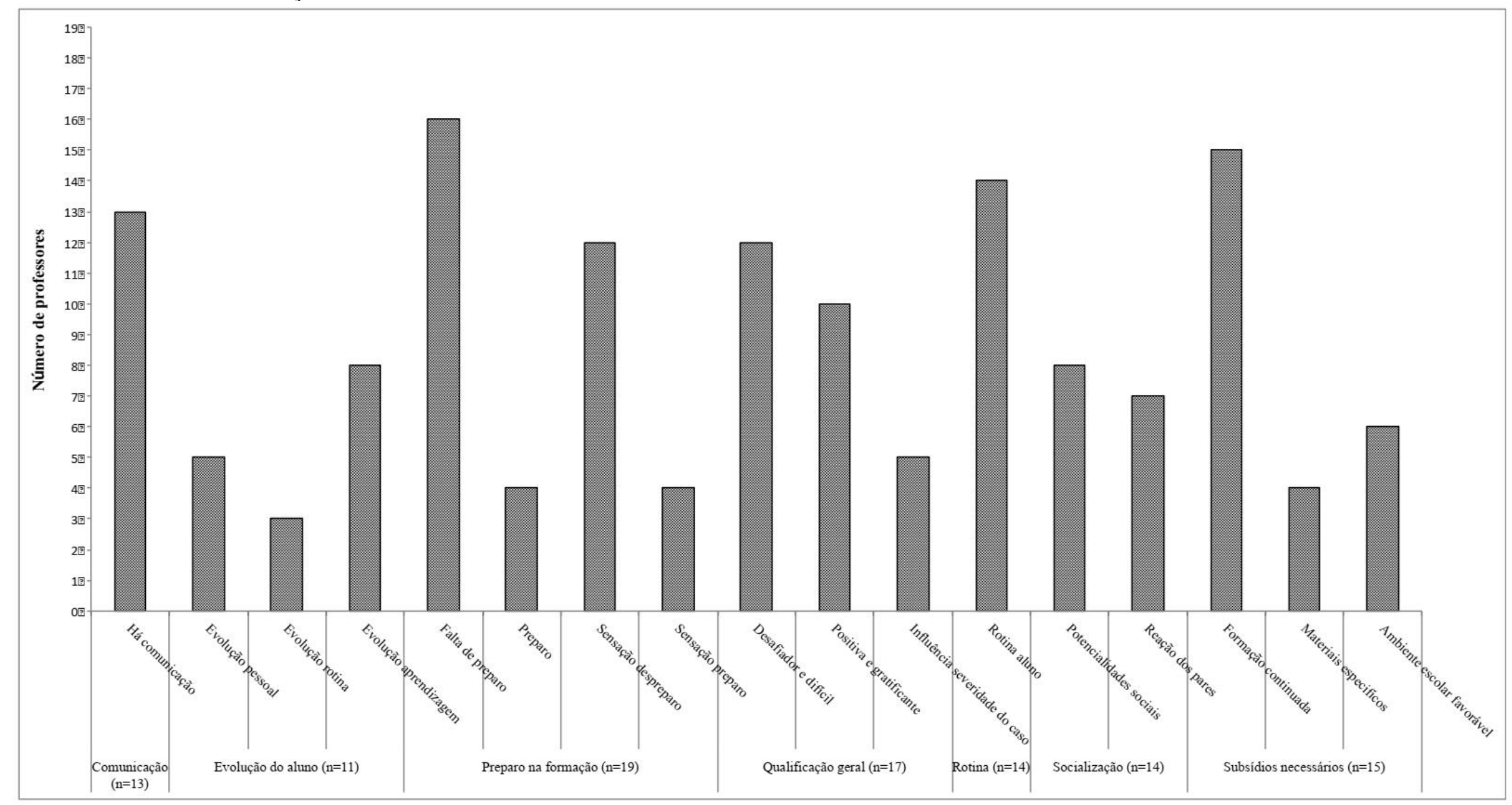

Fonte: Elaborado pelos autores. 
Em contrapartida, quatro professoras salientaram que se sentiam preparadas para atuar com alunos com TEA, seja por terem alguma formação na área, por meio de cursos, ou por terem se habituado ou trabalhado anteriormente com alunos autistas:

"Sim me sinto, mas não vem da formação, mas do desejo de fazer o melhor e da experiência em sala de aula especial." - Professora 9.

Embora o desconforto frente à inaptidão para o trabalho com alunos com autismo exerça um movimento positivo e importante por busca de conhecimento e alternativas de trabalho, quando não acompanhado de orientação adequada, o fazer pedagógico pode ficar prejudicado pelo uso de práticas e estratégias pouco efetivas. As professoras entrevistadas reconheceram que há um investimento significativo para participação de cursos na rede de ensino, procurando capacitá-las para o processo de inclusão na escola comum. Todavia, segundo elas, o conhecimento fornecido é muito geral e não atende às necessidades e às especificidades dos desafios e do trabalho diário:

\footnotetext{
"Sim, tive alguns cursos né, fiz há alguns anos, já fiz alguns cursos, algumas coisas assim para educação especial.” - Professora 11.

“É que é tão superficial, né?!" - Professora 8.

"Precisa o fundamental, mais prática. Bastante mais prática." - Professora 10.
}

Como resultado dessa carência de formação mais específica, relativa às necessidades, as professoras não conseguem exercer um trabalho pedagógico efetivo que atenda as demandas de seus alunos com TEA. Assim, 12 professoras consideraram essa experiência de ensino inclusivo com aluno com TEA desafiadora e difícil.

Apesar desses aspectos que geram desafios e tornam a experiência de inclusão de alunos com TEA difícil para as professoras, a experiência possibilitou um crescimento profissional. Muitas professoras repensaram as suas práticas pedagógicas e analisaram os benefícios que a inclusão pode gerar em seus alunos. Esse processo é importante, pois pode guiar o trabalho do professor, com o propósito de reconhecer os avanços possíveis, e refletir em objetivos mais bem definidos no processo de ensino-aprendizagem dos alunos com TEA. Em virtude disso, algumas professoras perceberam uma evolução significativa nos alunos com TEA em sua aprendizagem e socialização, como mostram as falas abaixo:

\footnotetext{
"Eu percebo que depois que ela veio pra escola, ela já fala meu nome e da professora auxiliar, lógico que na maneira dela. Ela copia o nome dela, dentro dos limites dela, ela evoluiu, né?” Professora 14.

"Principalmente no pátio. Ele gosta de brincar sozinho. Mas na sala de aula, a interação já é maior, porque ele participa, ele senta, ele vai pra mesa. Outro dia tava tocando a música, ele foi lá, pegou um amiguinho pela mão, começou a brincar de roda." - Professora 2.
}

A partir dos avanços salientados pelas professoras, pode-se observar que, mesmo sendo uma experiência desafiadora, elas reconhecem o papel de promover a inclusão desses alunos e empreendem esforços para que isso ocorra de uma maneira efetiva, apesar da rotina escolar desgastante e do problema recorrente da falta de recursos. Nesse sentido, dez professoras consideram a experiência como positiva e gratificante:

"Então eu qualifico assim, que às vezes a gente espera alguma coisa da criança e vem outra bem melhor do que aquilo que a gente esperava. Eu acho que são mais ganhos do que perdas pra gente." - Professora 12.

Além disso, sabe-se que cada criança com TEA apresenta características muito peculiares e o grau de severidade do transtorno influencia o trabalho pedagógico a ser realizado. Cinco professoras 
qualificaram a sua experiência de acordo com a influência desse aspecto, demonstrando que a possibilidade de inclusão está geralmente associada a casos de autismo menos severos:

"Essa experiência de hoje é mais tranquila. Atrapalha um pouco o andamento da aula, em alguns momentos sim, mas ela é mais tranquila porque o $\mathrm{K}$ não é um autista severo." Professora 10.

Apesar de considerarem um trabalho de aprimoramento constante e reconhecerem alguns avanços sociais e acadêmicos nos alunos resultantes de suas práticas, 15 professoras salientaram a necessidade de uma formação e orientação continuada para possibilitar um suporte maior no trabalho. Além disso, quatro professoras salientaram a necessidade de materiais específicos, que auxiliem no trabalho com alunos com TEA, como jogos e materiais visuais:

"Olha se eu conseguisse outras coisas seria maravilhoso... Eu tenho impressão que ele avançaria. [...] Jogos, eu precisaria de jogos, eu tenho muito pouco joguinho aí sabe? [...] Jogos pedagógicos, isso aí me ajuda um monte.” - Professora 6.

Também foi citada a necessidade de promover um ambiente escolar favorável para os alunos com TEA em que todos os integrantes da escola estejam unidos pelo mesmo objetivo, oportunizando que esse ambiente esteja adequado às necessidades dos alunos com TEA, conforme destacado abaixo:

\footnotetext{
"Uma coisa que eu vejo aqui na escola que é muito positiva, eu acho que na escola todo mundo aceitou bem a inclusão, porque desde servente à cozinheira, não é só as professoras e a direção, sabe? Elas têm um carinho, elas ajudam, elas vêm se oferecer se precisa de alguma coisa, se a cuidadora tá ocupada, chega assim e diz, mas se tu quiser, eu fico contigo aqui, sabe?" - Professora 4.
}

Sendo assim, é importante pensar meios de melhorar e aperfeiçoar o trabalho pedagógico com alunos com TEA na sala de aula para possibilitar um amplo espaço de vivência e aprendizagem rico de elementos que auxiliam na aquisição de habilidades sociais e acadêmicas. Esse espaço, enquanto fonte de experiências positivas para o desenvolvimento de crianças com autismo, pode ser potencializado se as dificuldades e as necessidades dos professores forem adequadamente atendidas para que as práticas pedagógicas, que vão ao encontro das necessidades educativas especiais desses alunos, sejam adotadas.

\section{CONSIDERAÇÕES FINAIS}

No decorrer da última década, é notório o investimento das políticas públicas no sentido de proporcionar o avanço das práticas inclusivas através de materiais e capacitações diversos para educadores e profissionais envolvidos no processo de inclusão de alunos com deficiências no ensino comum. No entanto, em relação à inclusão de alunos com TEA, nota-se, nos relatos das professoras entrevistadas, a percepção de que se tratam de eventos bastante gerais e inespecíficos em relação às problemáticas diariamente enfrentadas por elas no processo de escolarização dessas crianças. O estudo de Rosin-Pinola e Del Prette (2014), sobre a formação de professores, já indicava a necessidade de aperfeiçoamento de recursos de formação e assessoria para a inclusão voltados para alternativas práticas e sólidas levando em consideração os saberes e desafios cotidianos do professor. Neste estudo, buscou-se identificar as dificuldades pontuais e específicas encontradas por professores no processo educativo de crianças com TEA incluídas no ensino comum. Nesse aspecto, espera-se que seja possível fornecer subsídios para futuros programas de capacitação e instrumentalização de educadores e propor adequações e pesquisas que visem ao aprimoramento das práticas pedagógicas utilizadas com essas crianças. 
Ficou evidente, ao longo das entrevistas, que as professoras demonstram pouco domínio e conhecimento sobre o TEA, suas características e dificuldades e, sobretudo, sobre as práticas que seriam necessárias e mais apropriadas para indivíduos com autismo. Conforme apontado em estudos anteriores (NUNES; AZEVEDO; SCHMIDT, 2013; SCHMIDT et al., 2016; NASCIMENTO; CRUZ; BRAUN, 2017), a falta de conhecimento mais aprofundado e principalmente de cunho prático, que auxiliem no que e como fazer para ensinar e manejar as dificuldades comportamentais de alunos com TEA, encontra-se na base das dificuldades e dos desafios encontrados no trabalho diário com essas crianças. Embora em alguns casos prevaleça a associação da inclusão com casos menos severos de autismo, apreende-se, de maneira geral, que a percepção da maioria das professoras entrevistadas se afasta de um pensamento de resistência à inclusão, até pouco tempo recorrente no discurso de professores nas escolas e reportada em diversos estudos sobre o tema (ANJOS; ANDRADE; PEREIRA, 2009; OLIVEIRA-MENEGOTTO; MARTINI; LIPP, 2010; MENDES, 2006; SANT'ANA, 2005). O que fica explícito neste e em outros estudos (SCHMIDT et al., 2016) é um sentimento de frustração e impotência diante da escassez de conhecimento e de recursos perante as dificuldades de aprendizagem, comportamentais e sociais de alunos com autismo e da vontade de fazer mais e melhor para contribuir com seu progresso escolar e desenvolvimento. Tais sentimentos prejudicam o senso de autoeficácia do professor, ou seja, a confiança no seu trabalho como educadora, gerando tensão e estresse que influenciam na qualidade do seu trabalho (SANINI; BOSA, 2015; SCHMIDT et al., 2016). A busca por alternativas de trabalho que contemplem as dificuldades com o aluno com autismo revela o uso de práticas nem sempre adequadas ou validadas. Quando o uso de práticas adequadas e eficazes ocorrem, percebe-se que estas são atribuídas ao acaso ou ocorrem por coincidência de práticas executadas por tentativa e erro, e não pelo entendimento daquilo que tem sido demonstrado como mais eficaz. Isso demonstra a não utilização de práticas baseadas na evidência, uma tendência que tem sido vista como cada vez mais importante e necessária no campo educacional (CHRISTOPHE et al., 2015; DUNST; TRIVETTE, 2009).

Um dos princípios fundamentais da inclusão é o olhar e o repensar da escola e das práticas pedagógicas para as necessidades educacionais especiais dos alunos (STAINBACK, 2006). Nesse sentido, é preciso atentar para as necessidades de formação e de suporte específicos dos professores, que são os agentes de inclusão em contato direto e diário com os alunos (SERRA, 2010; MAZZOTTA; D’ANTINO, 2011). Em relação ao autismo, é notório que muitos mitos e muitas percepções equivocadas sobre como essas crianças aprendem e agem no ambiente escolar permeiam os discursos e as práticas das professoras. Embora nem todas tenham mencionado dificuldades pedagógicas no processo de ensino-aprendizagem do aluno com autismo, esse é um aspecto essencial de ser trabalhado com os professores, principalmente porque muitas vezes essas dificuldades, ou até mesmo a falta de dificuldades, estão atreladas a percepções equivocadas e ainda recorrentes de que o papel da inclusão para uma criança com autismo é o de oportunizar a socialização e não necessariamente de aprender e evoluir academicamente como os demais, ainda que em seu ritmo próprio (SCHMIDT et al., 2016).

Além disso, algumas falas demonstram que as professoras ainda associam equivocadamente a inclusão com atividades diferentes para o aluno com autismo e têm dificuldade para adaptar a atividade ou o recurso pedagógico de acordo com o nível e o estilo de aprendizagem do aluno, tal como preconiza a proposta da inclusão. Atentar para as necessidades do aluno não significa oferecer-lhe um currículo diferente, com conteúdos paralelos ao resto da turma, e sim adaptar ou modificar a forma de comunicar, ensinar e avaliar que, na maioria das vezes, são mais simples e fáceis de serem implementados e não requerem cargas extras de trabalho, como os professores comumente acreditam (OLIVEIRA, 2017). Adaptações simples na didática e no manejo da sala de aula são muitas vezes as principais mudanças necessárias e efetivas para promover a inclusão do aluno com autismo. De fato, a heterogeneidade das manifestações do transtorno podem contribuir para maior ou menor necessidade de modificações nas práticas pedagógicas. Entretanto, em grande parte, tais modificações são apropriadas e benéficas também para os colegas com desenvolvimento típico. $O$ desconhecimento e a falta de orientação adequada, explícita e focada em aspectos práticos leva os professores a buscarem alternativas pouco eficazes, em fontes informais e por vezes não confiáveis para guiar seu trabalho prejudicando, em muitos casos, o desenvolvimento e a permanência da criança no contexto escolar. $\mathrm{O}$ estabelecimento de rotinas claras e explícitas no ambiente escolar, por exemplo, é um auxílio essencial 
para organizar o ambiente, facilitar a aprendizagem e evitar crises comportamentais de todas as crianças, com ou sem deficiência (SCHMIDT et al., 2000). Apenas três professoras mencionaram dificuldades em estabelecer rotinas para o aluno com autismo. Isso não significa, no entanto, que as professoras que não mencionaram essa dificuldade utilizem esse recurso de forma apropriada. É possível que, ao não estabelecerem rotinas claras e definidas, ou não fazerem os alunos participarem ativamente dessa rotina, as professoras não identifiquem dificuldades em relação à inclusão do aluno com autismo nesse aspecto.

Essas observações e os dados relativos às principais dificuldades dos professores, quanto às características e práticas escolares diárias de alunos com autismo, apontam para uma necessidade fundamental de investimento em qualificação/capacitação das professoras para auxiliá-las com fundamentos importantes para o trabalho com essas crianças. Dessa forma, é possível fornecer subsídios essenciais para ensinar e avaliar a aprendizagem - algo que não se distancia da abordagem de planejamento que já deve ser tomada ou praticada com os outros alunos. Obviamente tal proposição não implica em tornar os professores do ensino comum em experts ou especialistas em autismo, mas conhecedores das especificidades do transtorno, das características dos seus alunos e das práticas baseadas na evidência que são úteis e essenciais para facilitar o trabalho e, de fato, promover a inclusão e o desenvolvimento desses alunos (SERRA, 2010; MAZZOTTA; D'ANTINO, 2011).

Para contribuir nesse sentido, destaca-se o papel do Atendimento Educacional Especializado e o trabalho complementar de apoio aos professores, previsto legalmente (ROPOLI et al., 2010). A urgência de formação continuada focada em necessidades específicas dos professores, em relação ao trabalho pedagógico diário com alunos com autismo, é evidenciada pelo contingente de professores em exercício da profissão cuja formação ocorreu antes de 2008, quando a implementação e discussão de práticas inclusivas ganha força nas escolas e nos cursos de formação de professores a partir da Política Nacional de Educação Especial na Perspectiva da Educação Inclusiva (2008). Antes disso, tais questões não eram sequer consideradas e mencionadas na formação do professor do ensino comum, uma vez que a educação da pessoa com deficiência restringia-se ao campo da Educação Especial. A própria produção acadêmica e científica nessa área ganha força a partir das elaborações das políticas inclusivas (NASCIMENTO; CRUZ; BRAUN, 2017). Das 19 professoras entrevistadas, apenas três mencionaram formação na perspectiva inclusiva após 2008. É natural que esse descompasso entre as práticas pedagógicas e as demandas da inclusão da criança com autismo ocorra e que as necessidades dos professores exijam um trabalho focado nas dificuldades diárias que são encontradas no trabalho com esses alunos.

Assim, com base nos resultados obtidos, identificam-se tais necessidades que podem ser consideradas nos cursos de formação inicial e continuada de professores e na elaboração de material educativo e instrucional com o objetivo de orientar os professores sobre as práticas educacionais efetivas disponíveis para crianças com autismo que vão ao encontro das dificuldades encontradas diariamente com esses alunos. Os resultados demonstram que as dificuldades mencionadas pelas professoras distribuem-se similarmente entre os diversos aspectos atrelados à díade de comprometimentos que o aluno com autismo possui nas áreas de comunicação/interação social e comportamento (ASSOCIAÇÃO PSIQUIÁTRICA AMERICANA, 2014). No entanto, destaca-se que, pela importância que esses aspectos possuem para o desenvolvimento de outras habilidades e para a escolarização de crianças com autismo, o pouco uso de estratégias adequadas para as dificuldades comportamentais (como evitar e manejar comportamentos que interferem no processo de ensinoaprendizagem) e pedagógicas (como ensinar e avaliar) requerem ainda mais investimento dos cursos de formação inicial e continuada de professores. Desse modo, será possível atender não somente as necessidades dos alunos, mas as necessidades dos professores a partir dos principais desafios que encontram no processo educativo das crianças com TEA que frequentemente apresentam dificuldades frente aos métodos de ensino tradicionais (DUTRA, 2008).

Além disso, este trabalho poderá servir de base para a ampliação do conhecimento sobre as práticas efetivas que favorecem a inclusão de crianças com autismo a partir de investigações posteriores sobre os benefícios e o impacto de uma formação inicial e continuada que contemplem as principais necessidades de conhecimento sobre o TEA e de como promover a efetiva inclusão e melhoria da qualidade de ensino e de vida oferecidos a essas crianças. As limitações deste estudo, como número 
reduzido de professores participantes, sendo somente da educação infantil e das séries iniciais e de uma única rede municipal de ensino público, limitam a generalidade dos dados e devem ser consideradas tanto no planejamento da formação continuada quanto na necessidade de pesquisas futuras que devem envolver amostras mais amplas e diversificadas.

\section{REFERÊNCIAS}

ALMEIDA, M. A. Colóquio. Revista Inclusão, v.4, n.1, p.18-32, 2008.

ANJOS, H, P.; ANDRADE, E, P.; PEREIRA, M, R. A inclusão escolar do ponto de vista dos professores: o processo de constituição de um discurso. Revista Brasileira de Educação, v.14, n.40, p.116-129, jan./abr., 2009.

ASSOCIAÇÃO PSIQUIÁTRICA AMERICANA. Manual diagnóstico e estatístico de transtornos mentais. Porto Alegre: Artes Médicas, 2014.

BAPTISTA, C. R.; OLIVEIRA, A. C. Lobos e médicos: primórdios na educação dos "diferentes". In BAPTISTA, C. R..; BOSA, C. A. Bosa (Eds.) Autismo e Educação: Reflexões e propostas de intervenção. Porto Alegre: Artmed, 2002.

BAPTISTA, C. R.; VASQUES, C. K.; RUBLESCKI. Educação e transtornos globais do desenvolvimento: em busca de possibilidades. Cadernos da APPOA, v.114, p.31-36, 2003.

BARDIN, L. Análise de conteúdo. Lisboa: Edições 70, 1977.

BIALER, M. A inclusão escolar nas autobiografias de autistas. Revista Quadrimestral da Associação Brasileira de Psicologia Escolar e Educacional, SP, v.19, n.3, p.485-492, set./dez., 2015.

BOSA, C. A. Autismo: intervenções psicoeducacionais. Revista Brasileira de Psiquiatria, v.28, p.4753. 2006.

BOSA, C. A. ; CAMARGO, S. P. Autismo e inclusão: Possibilidades e limites. In: GOMES, M. (Org.). Construindo as trilhas para a inclusão. 1 Ed. Vozes: Vozes, v.1, p. 90-215, 2009.

BRASIL. Constituição da República Federativa do Brasil de 1988. Brasília: Presidência da República, 1988. Disponível em:

<http://www.planalto.gov.br/ccivil_03/Constituicao/Constituicao.htm>. Acesso em: 06 nov., 2019.

BRASIL, Lei 8.069, de 13 de julho de 1990. Estatuto da Criança e do Adolescente. Brasília:

Presidência da República, 1990. Disponível em:

<http://www.planalto.gov.br/ccivil_03/leis/18069.htm>. Acesso em: 06 nov., 2019.

BRASIL. Política Nacional de Educação Especial na Perspectiva da Educação Inclusiva. Inclusão, v.4, n.1, p.7-17, 2008.

BRASIL, Lei 12.764, de 27 de dezembro de 2012. Política Nacional de Proteção dos direitos da Pessoa com Transtorno do Espectro Autista. Brasília: Presidência da República, 2012. Disponível em: <http://www.planalto.gov.br/ccivil_03/_Ato2011-2014/2012/Lei/L12764.htm>. Acesso em: 06 nov., 2019.

BRASIL, Lei $\mathbf{n}^{\mathbf{0}}$ 13.146, de 6 de julho de 2015. Institui a Lei brasileira de inclusão da pessoa com 
deficiência (Estatuto da pessoa com deficiência). Brasília: Presidência da República, 2015. Disponível em: < http://www.planalto.gov.br/ccivil_03/_Ato2015-2018/2015/Lei/L13146.htm>. Acesso em: 06 nov., 2019.

BRASIL. Resolução $\mathbf{n}^{\circ}$ 466, de 12 de dezembro de 2012. Ministério da Saúde. Conselho Nacional de Saúde, 2012.

CAMARGO, S. P.; BOSA, C. A. Competência social, inclusão escolar e autismo: Um estudo de caso comparativo. Psicologia: Teoria e Pesquisa, v.28, n.3, p.315-324, 2012.

CASTRO, J. M.; REGATTIERI, M. Interação Escola - família: subsídios para práticas escolares. Brasília: UNESCO, MEC, 2009.

CENTERS FOR DISEASE CONTROL AND PREVENTION. Changes in prevalence of parentreported Autism Spectrum Disorders. 2013 Disponível em:

<http://www.cdc.gov/media/releases/2013/a0320_autism_disorder.html>. Acesso em: 24 abr., 2013.

CHRISTOPHE, M.; et al. Educação baseada em evidências: como saber o que funciona em educação. Brasília: Instituto Alfa e Beto, 2015.

CRUZ, G, C.; et al. Formação continuada de professores inseridos em contextos educacionais inclusivos. Educar em Revista, Curitiba, Brasil, n.42, p.229-243, 2011.

DESSEN, M, A.; POLONIA, A, C. A família e a escola como contextos de desenvolvimento humano. Paideia, Ribeirão Preto, v.17, n.36, 2007.

DIAS, P. et al. Atitudes dos pares sobre a inclusão: Contributos da adaptação de um instrumento.

Psicologia, Lisboa, v.30, n.2, p.95-106, dez., 2016.

DUTRA, C. P. Colóquio. Revista Inclusão, v.4, n.1, p.18-32, 2008.

DUNST, C. J., TRIVETTE, C. M. Using research evidence to inform and evaluate early childhood intervention practices. Topics in Early Childhood Special Education, v.29, p.40-52, 2009.

FAVORETTO, N, C.; LAMÔNICA, D, A, C. Conhecimento de professores sobre Transtornos do Espectro Autístico. Rev. Bras. Ed. Esp., Marília, v.20, n.1, p.103-116, 2014.

FIORINI, M, L, S.; MANZINI, E, J. Dificuldades e Sucessos de Professores de Educação Física em Relação à Inclusão Escolar. Rev. Bras. Ed. Esp., Marília, v.22, n.1, p.9-64, 2016.

GOLDBERG, K., PINHEIRO, L. R. S. BOSA, C. A opção do professor pela área de educação especial e sua visão acerca de um trabalho inclusivo. Perspectiva, v. 107, p. 59-68, 2005.

GOMES, C, G, S.; MENDES, E, G. Escolarização inclusiva de alunos com autismo em Belo Horizonte. Rev. Bras. Ed. Esp., Marília, v.16, n.3, p.375-396, 2010.

GUTIERREZ, A, JR.; et al. Evaluating the social behavior of preschool children with autism in an inclusive playground setting. International Journal of Special Education, v.22, n.3, p.26-30, 2007.

HUNDERT, J. Inclusion of students with autism: using ABA-based supports in general. Austin: ProEd, 2009.

JÚNIOR, P. Casos de autismo sobem de 1 para cada 68 crianças. Revista Autismo. 2014. Disponível 
em: <www.revistaautismo.com.br>. Acesso em: 21 maio 2017.

LEMOS, E, L, M, D.; et al. Parents and teachers conceptions about the inclusion of autistic children. Revista de Psicologia, v.28, n.3, p.351-361, 2016.

MANTOAN, M, T, E. Inclusão: O que é? Por que? Como Fazer? São Paulo: Sumus, 2015.

MATOS, S, N.; MENDES, E, G. Demandas dos professores e inclusão escolar. Rev. Bras. Ed. Esp., Marília, v.21, n.1, p.9-22, 2015.

MAZZOTTA, M, J, S.; D'ANTINO, M, E, F. Inclusão social de pessoas com deficiências e necessidades especiais: cultura, educação e lazer. Saúde soc., v.20, n.2, p.377-389, 2011.

MENDES, E.G. A radicalização do debate sobre inclusão escolar no Brasil. Revista Brasileira de Educação, v.11, n.33, p.387-559, 2006.

NASCIMENTO, F, F., CRUZ, M, M.; BRAUN, P. Escolarização de pessoas com transtorno do espectro do autismo a partir da análise da produção científica disponível na Scielo- Brasil (2005-2015). Arquivos Analíticos de Políticas Educativas, v.24, n.125, 2017.

NUNES, P, D, R.; AZEVEDO, M, Q, O.; SCHMIDT, C. Inclusão educacional de pessoas com Autismo no Brasil: uma revisão da literatura. Revista Educação Especial, v.26, n.47, p.557-572, 2013.

OLIVEIRA, C, R. Educação Física escolar e inclusão de alunos com Transtorno do Espectro do Autismo. 2017. 122f. Dissertação (Mestrado em Educação) - Programa de Pós-Graduação em Educação, Faculdade de Educação, Universidade Federal de Pelotas. Pelotas, 2017.

OLIVEIRA-MENEGOTTO, L, M.; MARTINI, F, O.; LIPP, L, K. Inclusão de alunos com síndrome de Down: discursos dos professores. Fractal, Rev. Psicol., Rio de Janeiro, v.22, n.1, p.155168, Apr, 2010.

ROPOLI, E, A., et.al. A Escola comum Inclusiva. Brasília: SEE/UFC, 2010.

ROSIN-PINOLA, A, R.; DEL PRETTE, Z, A, P. Inclusão Escolar, Formação de Professores e a Assessoria Baseada em Habilidades Sociais Educativas. Rev. Bras. Ed. Esp., Marília, v.20, n.3, p.341356, jul./set., 2014.

SANINI, C.; BOSA, C. Autismo e inclusão na educação infantil: Crenças e autoeficácia da educadora. Estudos de Psicologia, v.20, n.3, p.173-183, jul./set., 2015.

SANT'ANA, I, M. Educação inclusiva: Concepções de professores e diretores. Psicologia em Estudo, v.10, p.227-234, 2005.

SANTOS, M, A.; SANTOS, M, F, S. Representações sociais de professores sobre o autismo infantil. Psicologia \& Sociedade, Belo Horizonte, v.24, n.2, p.364-372. 2012.

SCHMIDT, C., et al. Inclusão escolar e autismo: uma análise da percepção docente e práticas pedagógicas. Psicol. teor. prát., São Paulo, v.18, n.1, p.222-235, abr., 2016.

SCHMIDT, J.; et al. Effects of Using a Photographic Cueing Package During Routine School Transitions With a Child Who Has Autism. Mental Retardation: v.38, n.2, p.131-137, april, 2000. 
SERRA, D. Sobre a inclusão de alunos com autismo na escola regular. Quando o campo é quem escolhe a teoria. Revista de Psicologia, Fortaleza, v.1 n.2, p.163-176, jul./dez, 2010.

STAINBACK, S. Considerações contextuais e sistêmicas para a educação inclusiva. Revista Inclusão, n.3, p.8-14, 2006.

TERRA, R.; GOMES, C. Inclusão escolar: carências e desafios da formação e atuação profissional. Revista Educação Especial, v.26, n.45, p.109-124 jan./abr., 2013. 